Review Article

\title{
The Creative Revolution: The "New York in 1960" Experimental Era of Art and Design
}

Book: Art and Design in 1960s New York by Amanda Gluibizzi

Publisher: Anthem Press (26 February 2021)

Language: English

Hardcover: 256 pages

ISBN-10:1785276654

ISBN-13: 978-1785276651

\section{Dhaneshwar Shah}

School of Art and Design, Wuhan University of Technology, Wuhan, China

Email: dhaneshwar005@yahoo.co.in

\section{Introduction}

Welcome to New York in the 1960s! "Art and Design in 1960s New York," a key component of Amanda Gluibizzi's Doctor of Philosophy research at the "Graduate School of The Ohio State University," has been first published in the UK and USA in 2021 by Anthem Press, and the book is now available to acquire on major websites. Anthem Press is a leading independent academic, professional, and trade publisher with a strong international and interdisciplinary focus in the established and emerging social sciences, business/law, and humanities fields of study. The Rail's art editor is Amanda Gluibizzi, who is the co-founder and co-director of the New Foundation for Art History, as well as the author of the book titled "Art and Design in 1960s New York." She is a well-known art historian, researcher, and associate professor. She has a background in history, education, teaching, and publishing, as well as a specialisation in modern and contemporary art and design. Two of her notable research talks and papers are "Design Systems: What Not to Include" at the Wentworth Institute of Technology in Boston and "Making New York Understandable": Revolutionary Proposals for a City in Crisis-Design, History, and Revolution at Parsons New School in New York. The author takes a broader view of New York's "Visual World" in the 1960s. The author uses a formal approach to explore the relationship between art and design and highlight their mutual influence, which has been overlooked throughout history. The author employs ethnographic and multidisciplinary methods throughout the book to highlight the art and design experiments and challenges in 1960s New York. The author examines design and art side-by-side to explore how their relationship manifests itself. The author included quotations and excerpts from journals, books, magazines, newspapers, interviews, and film scenes, in addition to diverse analyses of visuals and literature cognate to art and design. This

This Open Access article is published under a Creative Commons Attribution Non-Commercial 4.0 International License (http://creativecommons.org/licenses/by-nc/4.0/), which permits non-commercial re-use, distribution, and reproduction in any medium, provided the original work is properly cited. For citation use the DOI. For commercial re-use, please contact editor@rupkatha.com. 
research-based book gives readers an opportunity to take a look back with curiosity at the art and graphic design of 1960s New York.

What exactly is New York? Is it a culture or a city? New York is known for its dynamism and diversity. New York's incredible multi-ethnic population has resulted in one of the world's most diverse cultures. The 1960s were a decade that left an indelible mark on leadership, design, self-expression, social shifts, and environmentalism. Change, optimism, tragedy, and disillusionment were all historical rituals of the 1960s. War, protest, hippies, rebellion, drugs, sex, peace, love, and rock 'n'roll characterised the 1960s. During the 1960s, civil rights, antiwar demonstrations, political assassinations, opposition to the Vietnam War, feminism, Mexican American activism, and environmental activism all arose, as did the first stirrings of gay rights and an ever-widening "Generation Gap" between parents and their more liberal offspring. From the executives of Madison Avenue to the artists of the East Village, New York in the 1960s was a city full of color, life, and diversity. New York City is home to numerous contemporary art galleries and auction houses in Manhattan and Brooklyn, including grand institutions like the Metropolitan Museum of Art and the Museum of Modern Art, as well as the Noguchi Museum and the Neue Galerie. During the 1960s, literature, art, dance, and theatre underwent a fascinating period of expansion and transformation. The 1960s were a pivotal period in twentieth-century art, with the rise of Pop Art, Op Art, Minimalism, Conceptual Art, Performance Art, and Feminist Art, among many other styles and movements. During the postwar consumer boom of the 1950s and 1960s, Pop Art embodied a sense of optimism and challenged fine art traditions by incorporating imagery from popular cultures, such as advertising, news, and mass media production. It included a variety of transformations, such as mediums, languages, aesthetics, experiments, and more. All of the artists shared a fascination with mass media, mass production, and mass culture. The arts reflected both the turbulent social and political trends of the time, as well as the influence of previous generations of artists and writers.

We're debating a number of recent transformations in the world, such as whether or not Bitcoin is accepted globally. Learn about the impact of artificial intelligence on our world, including visual art. Everyone was losing their mental balance and worried about healthcare services while imprisoned in their homes during the COVID-19 pandemic lockdown, regardless of whether the COVID-19 vaccine was safe to take. What was Amanda Gluibizzi doing at the time? Gluibizzi concentrated on improving her doctoral research so that it could be applied in the future as a valuable reference. Following the publication of this book, we are now forced to reconsider art and design applications, new theory, as well as the aesthetics, experiments, and visual language employed in New York during the 1960s. The book looks at issues such as the social and commercial environment, experiments, and their impact on art and design, as well as investigating the mutual influence of fine art and graphic design in New York City. The book follows design and art's evolving interest in responses to civic problems such as the proliferation of billboards, navigation through the city's streets and subways, and issues of deteriorating infrastructure, beginning with advertising's "Creative Revolution" and its relationship to pop artists. As a result of their strategies, artists and designers used similar approaches to visual imagery and shared techniques for thinking about and responding to the city in which they lived. With the help of Amanda Gluibizzi, let's look at the strategies that artists and designers used in the 1960s in New York. 
3 | The Creative Revolution: The "New York in 1960" Experimental Era of Art and Design

\section{Designs on 1960s New York: The Image of Pop and North by Northwest}

The first chapter, "Designs on 1960s New York: The Image of Pop and North by Northwest," focuses on Ogilvy's rules in the Advertising Directions, the influence of advertising elements on Pop Art, and the significance of Alfred Hitchcock's film North by Northwest's storyline and advertising imagery. The author looks at the film "North by Northwest" as a "Pop Art Case Study," directed by Alfred Hitchcock in 1959, which was about advertising design, advertising strategy, and advertising men. The term "Image" was also discussed in various places in this chapter, which has been used to describe Pop art and advertising as important elements. At that time, Pop artists were aware of the psychology of advertising design and openly adopted such strategies in their own work. The author used "North by Northwest" (1959) by Saul Bass as a key element to demonstrate Pop art characteristics. Bass, who designed the famous introduction in 1959, was an Oscar-winning graphic designer and filmmaker. Bass's iconic, minimal designs helped to brand a staggering number of major corporations. David Mackenzie Ogilvy, CBE, the "Father of Advertising" and founder of Ogilvy \& Mather, he refers to the use of bold, pure colours in poster design, which he refers to as primarily billboards. In addition, the author describes Roger $O$. Thornhill from a variety of perspectives at the time, the main character in North by Northwest. The author also debates various art and design rules, primarily those of Ogilvy and Bass.Suspension and the grid are two evocative elements that Bass experiments with. The grid system, isolation, and centred formality of the photographic imagery used on the film's poster reflect debates in art and design at the time about the role of the "Image" in Pop art and marketing.

\section{Breaking the Rules with the Beetle: Volkswagen's Revolutionary Advertising and the Visual Wit of Andy Warhol's Pop Art}

In the second chapter, "Breaking the Rules with the Beetle: Volkswagen's Revolutionary Advertising and the Visual Wit of Andy Warhol's Pop Art," the author claims that Warhol's Pop art repurposed advertising strategies such as those used by Volkswagen. The Volkswagen advertisements were so successful that the company was able to compare the shape of its previously unknown car to another shape "Known Around the World," the Coca-Cola bottle, only a few years into the campaign. What does Bill Bernbach's Volkswagen campaign from the 1960s mean? What do the Volkswagen commercials "Lemon." and "Think Small." mean? What was the advertising firm Doyle Dane and Bernbach's unique marketing strategy for selling beetles in America in the 1950s? Why did Volkswagen have such a hard time with marketing and advertising? This section describes Volkswagen's revolutionary campaign, breaking the rules with the Beetle and the visual wit of Andy Warhol's Pop Art in the name of "American" values. Peter Bart wrote an article for the New York Times in 1962, three years into Doyle Dane Bernbach's Volkswagen campaign, with the headline "Volkswagen Breaks the Rules." The "Lemon." print campaign was created by Doyle Dane Bernbach and focused on the Beetle's form, which was smaller than most of the cars on the market at the time. According to the advertisement, Volkswagen lasts longer, requires less maintenance, and is less expensive than other vehicles. "Think Small." was also one of the most well-known advertisements in Helmut Krone's advertising campaign for the Volkswagen Beetle. The Beetle received a lot of attention 
as a result of this one-of-a-kind advertising experiment. Another experiment in which Ogilvy broke advertising rules was with "2 Shapes Known the World Over," in which the Volkswagen Beetle, represented by Coca-Cola in 1962, was another advertising experiment. The author also briefly discusses the iconic images of "Coca-Cola" and "Coke Culture." Several artists at the time, including Robert Rauschenberg and Andy Warhol, used the "Coca-Cola Bottle" as a metaphor. In the middle of this chapter, we also came across "The Man in the Hathaway Shirt," which describes how the image of the Volkswagen took up two-thirds of the page, while the headline and copy took up the remaining third. Volkswagen chose the Futura "Geometric Sans Serif" font for a variety of reasons, including its resemblance to Volkswagen, which is also discussed in this chapter.

\section{Navigating by the Vernacular Glance: Billboards, Signs, and the Urban Combine}

"Navigating by the Vernacular Glance: Billboards, Signs, and the Urban Combine," the third chapter, looks at the widespread use of billboards in the mid-twentieth century, as well as the anti-billboard movement that attempted to regulate their placement and design. The author travels through Rauschenberg's work to see how he used street signs to elicit our rule-bound visual response to directional and informational signs, which manage city traffic. What kind of impact do such insinuating decisions have on the surrounding environment? How do repeated images, especially large-scale advertising like posters and billboards, interact with and against the ecosystems where they are placed? What's more, how do viewers navigate through such a cacophony? We must look beyond Warhol's work, which feels too graphically disciplined to provide an indication because it is single-image dependent, to consider such questions. Rather, you can look at Robert Rauschenberg's Combines and screen paintings in this chapter, which serve as microcosmic city vistas and guide us through them. The author examines several Rauschenberg works that contain navigational elements such as arrows, signs, or abstracted types of urban directional "Caution/Watch/Your Step" that serve as a guide. All of these signs have the appearance of billboards in urban areas. Many artists, such as Robert Rauschenberg, employ a variety of signs, texts, traffic signals, and readymade objects to represent their relationship with time, space, and the social impact on their ideology and artwork. Rauschenberg was receptive to the possibilities that physical expression offered.

\section{Way- Words: Wayfinding by Following Pieces}

The competition between billboards and street signs in New York City created a visual noise that bothered designers, as we saw in the previous chapter, but Robert Rauschenberg cleverly combined these in his artwork. Chapter Four, "Way-Words: Wayfinding by Following Pieces," examines the use of guides in late 1960s art and design. The author compares Unimark's underground intervention to Vito Acconci's Following Piece, a performance art project with a surprising correspondence, to investigate the ramifications of Unimark's underground intervention (1969). Bringing the action of signage and the action of the artist together in this way allows us to investigate the structural similarities and limitations of such endeavours as the following pieces. The primary issues of wayfinding signage system design are raised. To address 
5 | The Creative Revolution: The "New York in 1960" Experimental Era of Art and Design

such challenges, Noorda and Vignelli had to employ a variety of research strategies, including identifying areas in need of wayfinding signage, determining how the public used spaces like passageways, platforms, and waiting areas throughout the subway and commuter train system, and signaling the possibilities of such spaces. The author investigated how artists, designers, and viewers make paths and form systems in their environments by comparing design routines with Vito Acconci's performance, known as "Following Piece (1969)."This performance includes both written instructions from the artist as well as photographs documenting the performance. Here the author discussed how Acconci moved into the streets from the confines of galleries and how designers similarly moved from an almost exclusive focus on commercial design to concentrating more regularly on projects intended for the civic good. The author also went into great detail about the Noorda tree diagram.

\section{What's the Matter with the Megalopolis?}

"What's the Matter with the Megalopolis?" is the fifth chapter, which takes the reader to 1972 and the epicenter of New York City's art and design interactions. The author went into great detail through two prominent exhibitions, "Making New York Understandable" and "Making Megalopolis Matter: The Artists' Answer," both of which were installed at the New York Cultural Center in Manhattan in 1972 and debated the discomforts of city living and proposed possible solutions. The installation "Making New York Understandable" focused on design solutions to the city's problems. Graphic design, industrial design, and urban planning were among the designers featured in the exhibition. Another art exhibition, "Making Megalopolis Matter: The Artists Answer," was installed a month later. This exhibition featured a number of performance and installation artists who, in response to the design show's clarity and desire for order, argued for a shift toward a greater display of individualism on city streets and more opportunity for chaos. These two exhibitions featured performances and installations by Yoko Ono, Vito Acconci, Hans Haacke, and Gordon Matta-Clark, who provided an analysis of some of the artworks and artists from the late 1960s and early 1970s closely employed in design systems, such as those proposed by Unimark International. In the 1960s, New York artists and designers collaborated amongst themselves, sharing techniques for thinking about and responding to the city. The author also called attention to design forums such as "Design In," which borrowed tactics and graphics from the city's various protest movements in the 1960s. This revolution took the form of protest-inspired "Design Ins" and mayoral task forces in New York City, all of which called for more design attention to the city's needs.

\section{New York, 1960: The Creative Revolution}

In the present time, what can we discover from New York, New York in 1960, and art and design in 1960s New York? What is the significance of this book in today's world? Before I started reading this book, I had a lot of serious concerns. It appears that we are watching a classic black and white movie on the latest OLED television or Magic Box as we read this book. Seeing vintage advertisements such as the Volkswagen Beetle campaign "Lemon.," "Think Small.," or "The Man in the Hathaway Shirt" is a romantic experience in and of itself. Only a skilled 
magician, such as Amanda Globizz, could provide us with the time-travel experience that she demonstrated in this book. The author thanked diverse people for their contributions to her research, but she didn't forget to thank health care, emergency, and essential workers for their contributions to the rest of the world. The "New York in 1960" experimental era describes streets, buildings, and public spaces that have special meaning in the visual arts world. Revolutionary movements, new visual and conceptual aesthetics and a language for numerous avant-garde movements in art and design marked this period, which altered people's perceptions of space and the world. Designers and artists began investigating the problems that New York City was facing in 1960. We saw a variety of experiments in the advertisements that allowed Volkswagen to become a must-have brand for American intellectuals. Several case studies and examples show that designers and artists take civic design seriously because it contributes to new ways of living together. Additionally, by appropriating the language of protest movements, sit-in performance strategies, and the visual punch of placards, designers used their communication skills to reclaim the urban landscape from advertising and the city government. This book also serves as a reminder of the social responsibilities of designers and artists in the city and society in which we live. The connections between art, design, history, revolution and challenging moments of social, political, economic, urbanisation, industrialization, aesthetic, experimentation, technological, and other upheavals are explored in this interdisciplinary book. "New York 1960" is a philosophy or concept rather than an era, city, or location that "Amanda Gluibizzi" attempted to formulate, and whose navigation is still visible in the work of many artists and designers today.

\section{Notes:}

1. Note: All terms and references used are from "Art and Design in 1960s New York" by Amanda Gluibizzi (Author).

2. The book can be purchased at https://anthempress.com.

Dhaneshwar Shah is an artist and a PhD candidate in the Department of Art Theory at the School of Art \& Design, Wuhan University of Technology, China. His research looks at how Asian contemporary artists use traditional mediums, techniques, and experiments to express various types of identity. He has been exploring this phenomenon from different perspectives in both his research and practices. 